terms. It can be obtained from the publishers, Newnes Educational Publishing Co., Tower House, Southampton Street, Strand, London, W.C.2.

\section{Grants to Students in Britain}

A MEMORANDUM submitted by the National Union of Students to the Committee on Grants to Students set up by the Minister of Education and Secretary of State for Scotland under Sir Colin Anderson as chairman has now been published (pp. 28. London: National Union of Students, 1959). Its seventeen recommendations include the financing of awards entirely by the Government and administration by a central grant-awarding authority, or alternatively and as an interim measure, that the awards should be financed mainly by the Ministry of Education, with a proportion to be met from a pool to which all local education authorities should contribute. Awards should be given to those selected by universities for first-degree courses and for comparable courses in other institutions of higher education and the relevant authorities should be invited to review the standard set in 'closed' scholarship examinations. University authorities are urged to consider the practicability of establishing a clearing house system for dealing with university applications, and a review of the values of university scholarships and removal of their maintenance factor are also recommended. In the light of the university review an honorarium for State scholars should be agreed, while the system of supplementation by the Ministry should be ended and the numbers of State scholarships offered should be reviewed each year. Non-recurrent prizes gained in open competition during the course should be tenable without reduction of grant, and awards should also be granted on acceptance to students taking full-time or sandwich courses of degree study at technical colleges or courses recognized by the Ministry of Education as being of comparable status, and these awards should be assessed on the State scale for major awards. It is also recommended that awards should be made without reference to the parental income and that the values of awards should be reviewed every two years instead of every three years.

\section{Graduates in British Industry}

THE Information Division of the Department of Scientific and Industrial Research has issued under the title "Graduates in British Industry" (pp. iv + 28. London, 1958) a short record of the main findings and applications likely to be of value to firms recruiting graduates, and also to graduates newly appointed to jobs in industry, of the two reports "Graduate Employment-a Sample Survey" and "Graduates in Industry" published by Political and Economic Planning. The record is illustrated with diagrams and the main pointers for management are summarized in the final section. The conclusions from the inquiry are also given concisely following eight short sections dealing with various aspects of the subject.

\section{Atmospheric Temperatures}

METEORoLogists, aviators, and those concerned with the planning of air routes, often require information about the winds and temperatures which may be expected in different parts of the globe at varions levels. Winds are usually more important, and the Meteorological Office published its Geophysical Memoir No. 85 some time ago to meet this urgent need. Now a companion Memoir, No. 101, has been published, giving temperature information for all parts of the Earth except those regions south of latitude $60^{\circ} \mathrm{S}$., mainly at the standard pressurelevels $700,500,300,200,150$ and $100 \mathrm{mb}$., which range from $10,000 \mathrm{ft}$. to $56,000 \mathrm{ft}$. approximately. The presentation involves variation with place, height and time, and is necessarily done graphically, but the nature of the variations is complicated by the variations in the tropopause-level. When any point is sometimes in the troposphere and sometimes in the stratosphere, the temperature variations are normally bimodal, that is to say, the distribution curve shows two peaks, one corresponding to tropospheric and the other to stratospheric events. In this case, special care must be taken in interpreting the data, and it is inevitable that the Memoir contains a great deal of information about the tropopause and its average movements. This, particularly, will interest the meteorologist. The sources of the data have been carefully listed; but a map showing the distribution of the observing points might have been a valuable guide to the extent to which it has been necessary to interpolate over various areas. For example, it has not been possible to include any data since 1952, and sometimes data from adjacent areas are taken for different years. This must sometimes cause apparent changes from place to place due to the different regimes which occur in different years, and there must be very few results from areas between $35^{\circ} \mathrm{S}$. and $60^{\circ} \mathrm{S}$. The present Memoir is welcome, but even though it has just appeared we shall look forward to a new edition, revised in the light of the very much greater volume of information obtained during the International Geophysical Year.

\section{Assistance from the International Atomic Energy Agency}

A PAMPHLET, "Technical Assistance" (pp. 16. Vienna: International Atomic Energy Agency, 1958), outlines the services available from the International Atomic Energy Agency, describing first the kinds of assistance, including fellowships and exchange visits, the provision of advice and information on nuclear energy problems and equipment, and secondly the fields in which member States can request assistance from the Agency. Those listed include library and documentation services; ore prospecting, mining and processing; the design, construction and management of nuclear research laboratories and centres; nuclear research ; nuclear reactors ; the use of radioisotopes ; safeguards ; and problems of health, safety and disposal of waste. Thirdly, rules and practices governing assistance are detailed.

\section{Craters on the Moon}

RECENT reports of a volcanic eruption near the lunar crater Alphonsus have apparently stimulated fresh experiments and speculation on the origin of these craters. Apart from the well-known meteoritie and voleanic theories, F. Benario suggested some years ago (The Strolling Astronomer, 7, $19 ; 1953$ ) that a bursting bubble of gas could produce a crater of similar form. In a recent letter, Dr. A. G. Gaydon and R. C. M. Learner (Nature, 183, 37 ; 1959) showed photographs of crater-like formations produced by gas effusing through a light dry powder under vacuum. There appears to be some confusion between the two latter experiments, which are in reality quite different. In Benario's work, the sudden bursting of 